\title{
エイジングによる材面の見えの変化と画像特徵量の関係†
}

\author{
細川 璃紗* 仲村 匡司** 小林 秀平***
}

\section{Determination of Changes in Appearance of Aged Lumber Surfaces by Image Characteristics}

by

\author{
Risa HOSOKAWA*, Masashi NAKAMURA** and Shuhei KOBAYASHI***
}

\begin{abstract}
Changes in appearance of every product by the aging are inevitable. Such changes are considered as the deterioration easily connecting to negative impressions to various products. On the other hand, the changes in the appearance of wooden products by the aging may create new aesthetic values such as "antique" and "vintage". The objectives of the present study are to extract image characteristics related to the change in the appearance of lumber surface caused by the aging and to investigate relationships between them and sensory evaluation or attractiveness. Twenty-five quasi-aged wood specimens with $300 \mathrm{~mm}$ square were prepared by a skilled painter's techniques. Digital image data with the true chromatic information of the specimens were captured by an imaging spectrometer and two kinds of image analyses were applied to the data. Forty university students evaluated the appearance of the specimens subjectively such as "antiquity" and "aesthetics by aging", and the eye movements of another fifteen university students observing the specimens were recorded using an eye tracker. The surface lightness and its variation strongly affected the subjective antiquities of the specimens. The eye tracking revealed that the participants tended to gaze frequently at characters of a specimen surface such as distinct flat grain's vertexes or dirty stains.
\end{abstract}

\section{Key words}

Aged wood surface, Image analysis, Imaging spectroscopy, Histogram analysis, Multiresolution contrast analysis, Sensory evaluation, Eye tracking

\section{1 緒}

木材はいにしえより, 人類の発展のために多くの異な る役割（建築，道具，家具，エネルギーなど）を果たして きた. そして, 我々にとって最も重要な材料のひとつとし て, 今なおその価值を保っている. その理由のひとつは, 木材が建築物を支える構造用材としても，居住者とのイ ンタフェイスとなる内装用材としても利用できることに あろう. 特に後者として木材を利用する場合, 人が直接木 材を見たり触れたりすることになるため，色や柄などの 外観的特徵への配慮が必要となる.

木材は, 光や熱, 空気, 外力, 菌類などの影響を受けて, その表面状態が経年変化する。このエイジングは, 木材に 限らず種々の材料の使用中に，あるいは保管中に，その物 理的, 化学的, あるいは力学的な特性に生じた不可逆的な 変化とみなせる。エイジングによって木材や木製品の表 面に生じた変化は, 多くの場合, その美観や耐久性の衰え に直結する「劣化」であり，望ましくないとされる．その 一方で，古い木造建築や使い込まれた木製家具などに現 れる外観上の変化は，しばしば「アンティーク」や「ヴィ
ンテージ」などと称される.これは製品の新しい価值につ ながる望ましい変化とみなせる。

木製品に限らず，我々が生活の中で使用する様々な製 品の外観は, 当然のことながら使用開始時が最も美しい. その後, エイジングによってその美観は徐々に損なわれ ていき, やがて美観の許容ラインを下回り, 廃棄に至る. ただし, 木製品の場合, エイジングによってある程度まで 美観が衰えてもあるタイミングで下げ止まり，場合によ っては美観が V 字回復を果たすことがあり，このとき， 「趣き」や「落ち着き」といった新しい価值を獲得する。 エイジングによる木材の外観上の変化を数值で表現す るために, 測色計による材色の測定が多数行われてきた ${ }^{1)}$. また，熱処理や紫外線放射処理によって人工的にエイジ ングを再現し，その材面の測色を行った事例も報告され ている ${ }^{2)}$ 4). ただし, その測色の多くは測定孔径数 $\mathrm{mm} \sim$ 数 $\mathrm{cm}$ のスポット測定に限定されており, 材面の数ヶ所を 測定した平均值を代表值として， L*a*b*表色系の $L^{*}$ 值, $a^{*}$ 值， $b^{*}$ 值あるいは色差 $\Delta E^{*}$ が経年によってどのくらい 変わったかを議論することが多い. しかし, そもそも材面

$\dagger$ 原稿受理 令和 2年 12月 7日 Received Dec. 7, 2020 C2021 The Society of Materials Science, Japan

* 京都大学大学院農学研究科 $\bar{T} 606-8502$ 京都市左京区北白川追分町,

Division of Forest and Biomaterials Science, Graduate school of Agriculture, Kyoto University, Sakyo-ku, Kyoto, 606-8502

** 正会員 京都大学大学院農学研究科 ₹606-8502 京都市左京区北白川追分町,

Division of Forest and Biomaterials Science, Graduate school of Agriculture, Kyoto University, Sakyo-ku, Kyoto, 606-8502

*** (株)LIXIL人間科学研究所 $\bar{T} 270-0237$ 野田市中里 3000

Human Science Laboratory, LIXIL Corporation, No. 3000, Nakazato, Noda, 270-0237 
の色調は均一ではなく, 経年変化も材面全体で均質に進 行するわけではない.「アンティーク」や「ヴィンテージ」 などのエイジングによる新しい価值の源は，材色のちょ うどよい「不均一さ」にあると仮定すると，これを従来の スポット測定で把握することは困難である. また, そのよ うな測定法で得られた色彩值で材面の見た目の印象を説 明することも難しいと考えられる.

この難点を克服するためには「面的測色」の導入が必要 である. 田代ら ${ }^{5}$ は, 面的測色を可能にするイメージング 分光法を, 透明塗装による材色変化の精密測色に適用し, 画像データと同様に扱える色彩值を取得して，ヒストグ ラム解析および多重解像度コントラスト解析を行った。 本研究の目的は, 田代らと同様の手法を用いて, 経年の程 度が異なる材面の外観的特徵を定量的に抽出し, その材 面の主観的な「古さ」との対応関係を明らかにすることに ある.さらに, 観察者が材面のどのような特徴に注目する のか，エイジングによる誘目性の変化の検証を試みる.

\section{2 方 法}

\section{$2 \cdot 1$ 試料の調製}

エイジングによるどのような変化が材面の主観的な 「古さ」や誘目性に影響を与えるのかを明らかにするた めに, 経年による外観上の「古さ」が段階的に異なる木材 試料を調製した.ただし, 実際にエイジングを行うのは時 間的に困難であるので，今回は古色付けの技術を有する 塗装職人に依頼して, 経年変化の進行を塗装で表現する こととした.

そのような塗装処理を施す基材として，ホワイトオー ク（Quercus alba，環孔材）およびハードメイプル (Acer saccharum, 散孔材) の連続スライス単板を突いた $300 \mathrm{~mm}$ 角, $9 \mathrm{~mm}$ 厚の化粧合板を多数用意した. 各樹種の同一フ リッチから連続スライスされた単板を突いたので，各樹 種の木目柄はほぼ同一とみなせた.また, オーク材試料に ついては, ライト, ナチュラル, ダークの 3 色を, メイプ ル材試料についてはライトとナチュラルの 2 色を, それ ぞれ基本色に設定した。これらの樹種や基本色の選択は, 家具や建装材などとして実際に多用されていることを考 慮したものである.これらの 5 系統それぞれについて, 経 年の程度すなわち「古さ」が 5 段階異なる試料を調製し た.

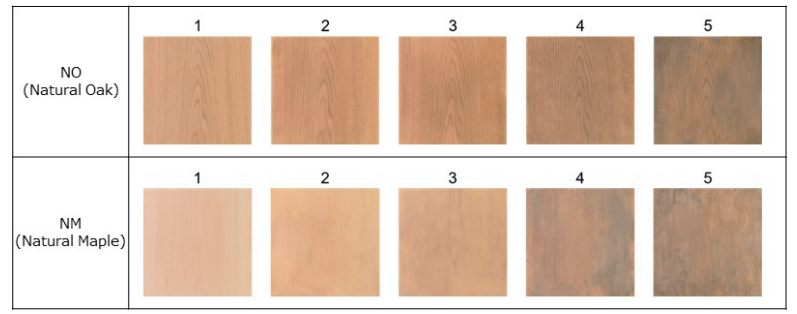

Fig.1 Example of aged wood specimens prepared for the present study.

Upper: natural oak (NO) specimens, lower: natural maple (NM) specimens. Numbers above images express degree of the aging.
Fig.1 にナチュラル・オーク系統およびナチュラル・メ イプル系統の試料を示寸. なお，以下では，2文字のアル ファベットを組み合わせて，LO（ライト・オーク系統）, NO (ナチュラル・オーク系統), DO (ダーク・オーク系 統), LM (ライト・メイプル系統), NM (ナチュラル・メ イプル系統）のように 5 系統を表現する。 また，これに 1 ～5 の数字を付して, 数字が大きいほど「古く」見えるよ うに塗装されていることを表すこととする.

\section{$2 \cdot 2$ 画像解析}

$2 \cdot 2 \cdot 1$ イメージング分光装置による画像入力 本研 究で使用したイメージング分光装置 (ImSpectorV8E，JFE テクノリサーチ) の動作原理は田代ら ${ }^{5)}$ に詳しいので, こ こでは概要を述べる。本装置は RGB 值ではなく XYZ 表 色系または $\mathrm{L} * \mathrm{a} * \mathrm{~b}$ *表色系の色彩值で表された画像デー夕 を取得できる, 一種のラインスキャナである.この装置で 最も重要なのは, 試料面を捉えるレンズとモノクロ CCD カメラの間にある鏡筒部で, ここに仕込まれたプリズム・ グレーティング・プリズム (PGP) がスリットを通過して きた平面光を分光して, $\mathrm{CCD}$ センサに展開する. このと き, $\mathrm{CCD}$ センサの左右方向は試料面に設定されたライン 上の画素の位置に, 上下方向は PGP が分光した光の波長 （380〜 780 nm の可視光域）に対応し, 各画素の分光強度 スペクトルが得られる. 試料を一方向に一定間隔でずら しながらラインスキャンしていくことで, 試料面の任意 の範囲の全画素について可視光域での分光反射強度を取 得できる. この分光反射強度は, 装置の校正時に標準白色 板を用いて設定された最大分光反射強度から分光反射率 に変換される. 試料面への入射光の分光強度と人の目の センサ感度に対応する等色関数は装置にプリセットされ ており, ここに分光反射率が手に入ることによって, 三刺 激值 $X Y Z$ や $L^{*} a^{*} b^{*}$ 值を画素ごとに算出できる. 画素の分 解能は, 撮像距離やレンズの画角を操作することにより 任意に変更できる. したがって, イメージング分光装置は, 実寸 $1 \mathrm{~mm}$ 未満の 1 画素単位での精密測色も, スキャンし た広い範囲の真の平均測色值なども得ることができる.

本研究では, 分解能を約 $0.21 \mathrm{~mm} / \mathrm{pixel}$ に設定して, 400 $\sim 750 \mathrm{~nm}$ の可視光域を $5 \mathrm{~nm}$ のピッチでスキャンし, 実寸 $215 \mathrm{~mm}$ 角の範囲から約 130 万画素の色彩值付き画像デー 夕を得た. 各画素の $L^{*} a^{*} b^{*}$ 值から, メトリック明度 $L^{*}$, 彩度 $C^{*}$, 色相角度 $H^{\circ}$ を求め, 画像解析に供した.

$2 \cdot 2 \cdot 2$ ヒストグラム解析 材面の全体的な色調を把 握するために, 取得した色彩值付き画像データから明度 $L^{*}$, 彩度 $C^{*}$, 色相角度 $H^{\circ}$ 色属性別にヒストグラムを作 成した. また, 測定範囲全域の真の平均值 (一次統計量), 標準偏差 (二次統計量), 歪度 (わいど, 三次統計量) も 色属性ごとにそれぞれ算出した。

$2 \cdot 2 \cdot 3$ 多重解像度コントラスト解析 材面の局所的 な特徵を把握するために, 色彩值付き画像デー夕を多重 解像度コントラスト解析 (Multi-resolution contrast analysis; MRCA）に供し, 田代ら ${ }^{5)}$ と同様に明度差 $\Delta L^{*}$, 彩度差 $\Delta C^{*}$, 
色相差 $\Delta H^{*}$ ，色差 $\Delta E^{*}$ に対応する 4 種類のコントラスト スペクトルを求めた. MRCA は Nakamura らによって考案 された画像解析手法である ${ }^{6)-8)}$. この手法では，2 次元の 画像データに 1 辺 $k$ の平均化フィルタ処理を施して，画 像を粗視化し, $3 \times 3$ の局所領域をこの画像中に設定して, 中央の標的ブロックとその周囲の 8 つの近傍ブロックと の色彩值の差を求める (局所コントラスト). 局所領域を 画像中に隈なく設定して，画像全域にわたって網羅的に 局所コントラスト計算を行い, その平均值を算出する. こ れにより，フィルタサイズ $k$ に対応する大きさの特徴が どのくらい目立ちやすいかをコントラスト值として検出 することが可能となる．フィルタサイズ $k$ を種々変更し てコントラスト計算を行うことで，フィルタサイズ $k$ の 関数としてコントラストスペクトルが得られる.

\section{$2 \cdot 3$ 主観評価実験}

2・3・1 実施環境 高演色性の蛍光管 $(\mathrm{FL} 20 \mathrm{~S} \cdot \mathrm{N}-\mathrm{EDL} \cdot$ $\mathrm{NU}$ ，パナソニック）を照明として組み込んだ呈示台を卓 上に設置し，ここに試料を，水平面に対して $20^{\circ}$ 傾けて 配置した. 被験者はその試料を，立位にて約 $700 \mathrm{~mm}$ の距 離から観察した。観察時は室内の天井光を消灯し, 試料面 の照度を約 750 lx に保った。また，同時に 4 名までの観 察を可能とした. Fig.2 左に実験風景を示す.

2・3・2 被験者 40 名の大学生（男性 21 名, 女性 19 名）が被験者として実験に参加した. 被験者の平均年齢は $21.7 \pm 1.6$ 歳, 平均視力は $0.9 \pm 0.2$ であった

$\mathbf{2} \cdot \mathbf{3} \cdot \mathbf{3}$ 主観評価 塗装職人が意図した「古さ」が見 る者に伝わるかどうか確認するため，また，被験者にす心゙ ての試料を一通り確認させるために，系統別に無作為に 並べられた 5 試料を自由に被験者に観察させ，その系統 内での古さの順位を調査票に記入させた．系統の呈示順 序や，系統内での 5 試料の配置は，最大 4 名の被験者グ ループごとにランダマイズした。この順位付けに要する 時間は，1 系統につき約 90 秒間であった.

次に, 25 種類の試料を無作為な順番で 1 枚ずつ呈示し て被験者に観察させ，「新しい一古い」「不快な一快い」な どの形容詞対を用いた両極尺度 10 種類，「味わい深さ」

「経年による美しさ」を評価させる単極尺度 2 種類を評 価させた. 評価法には無段階評価を行える Visual Analogue Scale (VAS) 法を用いた. 評価に要する時間は 1 試料につ き約 1 分間であった。集計にあたっては, VAS の左端を 0 , 右端を 1 として評価を数值化した.

\section{$2 \cdot 4$ 視線追跡実験}

$2 \cdot 4 \cdot 1$ 実施環境 試料を被験者の目の高さで垂直に 呈示できる観察ブースを作製し，試料面を上述と同様の
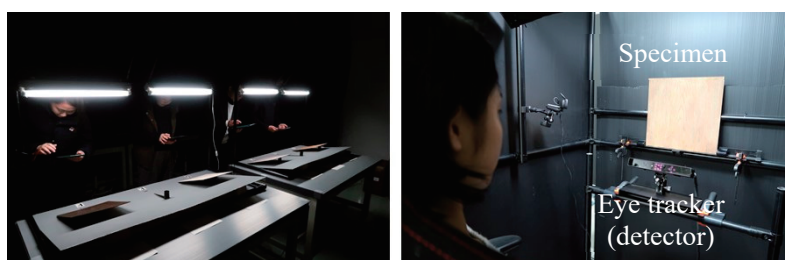

Fig. 2 Sceneries of sensory evaluation (left) and eye tracking (right)
高演色性蛍光管で照明した。試料面の照度は約 $420 \mathrm{~lx}$ で あった.この観察ブースにおける試料の観察距離は 700 $\mathrm{mm}$ であった. 実験中は屋内の天井光を消灯し, また, 周 囲の雑音を遮断するために, 被験者にイヤーマフを装着 させた．Fig. 2 右に実験風景を示す。

$2 \cdot 4 \cdot 2$ 被験者 15 名の大学生（男性 9 名, 女性 6 名) が被験者として実験に参加した. 被験者の平均年齢は 21.6 \pm 1.7 歳, 平均視力は $1.1 \pm 0.2$ であった.

$2 \cdot 4 \cdot 3$ 視線追跡および主観評価 ナチュラル・オー ク $(\mathrm{NO})$ 系統とナチュラル・メイプル $(\mathrm{NM})$ 系統の 10 試料を 1 つずつ被験者に呈示し, 30 秒間自由に観察させた.この ときの被験者の眼球運動を, 視線追跡装置 (EMR-ACTUS, ナックイメージテクノロジー) を用いて, 非接触で測定し, 被験者の視線の向いた先の座標（注視点）や睲孔径などを サンプリング周波数 $60 \mathrm{~Hz}$ で得た. 試料の呈示順序は被 験者ごとにランダマイズした.

さらに被験者には, 1 つの試料の自由観察が終わるごと に，その試料を再度観察しながらその見た目の印象を， 2.3.3 項と同様に VAS 法で評価させた.

\section{3 結果と考察}

\section{$3 \cdot 1$ 画像解析}

3・1・1 ヒストグラム解析 ヒストグラムの典型例と して, NM 系統の 5 試料の場合を Fig. 3 に示す. Fig. 3 に 示されているように, 材面が「古く」なるにつれて, 明度 $L^{*}$ 分布は低明度側にシフトし, 彩度 $C^{*}$ の分布はいった ん高彩度側にシフトしてから低彩度側にシフトした。ま た，色相角度 $H^{\circ}$ の変化はわずかであった．同様のヒスト グラムの遷移が LM 系統，LO 系統，そしてNO 系統でも 認められ，「古く」なるにつれて材面が全体的に暗くなり， くすんだといえる. 一方, DO 系統はこれら 4 系統と異な り，「古く」なるにつれて明度および彩度のヒストグラム がそれぞれ高明度側および高彩度側にシフトし, 色相角 度のヒストグラムは黄色 (色相角度大) 側にシフトした。 すなわち，「古く」なるにつれて材面が明るく鮮やかにな り，黄みが増したのである。

ヒストグラムに現れたもうひとつの特徴として，いず れの系統においても「古く」なるにつれて明度, 彩度, 色 相の分布が広がる傾向にあることがあげられる，明度で あれば，明るい部分と暗い部分の差が拡がることに対応 し，材面全体でコントラストが大きくなり色彩のバリエ ーションが増したことを意味する。

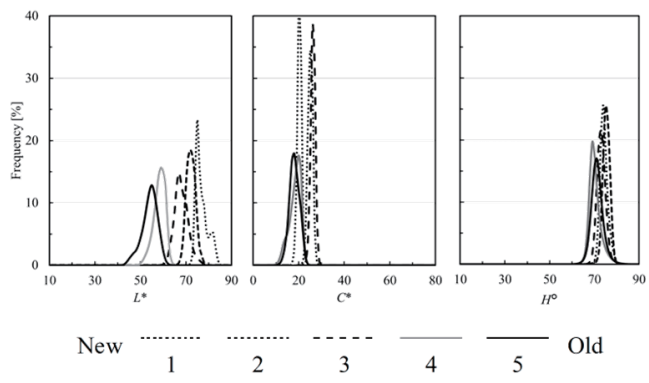

Fig. 3 Histogram transition in natural maple (NM) specimens. 
Table 1 Colorimetric statistics of specimens.

\begin{tabular}{|c|c|c|c|c|c|c|c|c|c|c|}
\hline \multirow{2}{*}{\multicolumn{2}{|c|}{ Specimen name }} & \multicolumn{3}{|c|}{ Mean } & \multicolumn{3}{|c|}{ Standard Deviation } & \multicolumn{3}{|c|}{ Skewness } \\
\hline & & $L^{*}$ & $C^{*}$ & $H^{\circ}$ & $L^{*}$ & $C^{*}$ & $H^{\circ}$ & $L^{*}$ & $C^{*}$ & $H^{\circ}$ \\
\hline \multirow{5}{*}{ LO } & 1 & 78.53 & 12.24 & 73.32 & 1.83 & 1.39 & 3.21 & -0.10 & 0.08 & -0.17 \\
\hline & 2 & 80.60 & 11.24 & 74.61 & 2.08 & 2.01 & 3.97 & -0.23 & 0.09 & 0.26 \\
\hline & 3 & 75.74 & 10.81 & 67.98 & 2.98 & 2.26 & 3.75 & 0.34 & 0.52 & -0.55 \\
\hline & 4 & 72.48 & 11.41 & 69.40 & 2.90 & 2.30 & 3.69 & 0.03 & 0.46 & 0.36 \\
\hline & 5 & 71.75 & 9.99 & 64.22 & 4.61 & 1.90 & 4.24 & -0.40 & 0.06 & -0.15 \\
\hline \multirow{5}{*}{ NO } & 1 & 66.28 & 24.05 & 72.45 & 2.82 & 1.87 & 2.84 & -0.54 & 1.24 & -0.56 \\
\hline & 2 & 61.42 & 27.60 & 70.08 & 3.32 & 1.53 & 2.60 & -0.02 & -0.05 & -0.62 \\
\hline & 3 & 58.00 & 28.27 & 68.64 & 3.56 & 1.79 & 3.12 & -0.46 & -0.53 & -1.01 \\
\hline & 4 & 52.42 & 24.16 & 67.89 & 4.14 & 2.71 & 5.00 & -0.22 & -1.17 & 0.13 \\
\hline & 5 & 49.79 & 19.67 & 67.84 & 3.28 & 3.06 & 3.80 & -0.24 & -0.12 & 0.48 \\
\hline \multirow{5}{*}{ DO } & 1 & 22.62 & 7.61 & 49.09 & 1.80 & 1.95 & 6.18 & 0.15 & 0.07 & 12.74 \\
\hline & 2 & 28.15 & 11.91 & 54.54 & 2.00 & 2.61 & 4.56 & 0.81 & 0.36 & 1.31 \\
\hline & 3 & 30.90 & 13.41 & 56.99 & 3.16 & 3.62 & 5.31 & 1.12 & 0.47 & 0.27 \\
\hline & 4 & 36.73 & 17.18 & 61.93 & 3.71 & 3.28 & 5.51 & 0.25 & -0.36 & 1.21 \\
\hline & 5 & 41.58 & 14.02 & 72.64 & 3.33 & 2.27 & 5.11 & 0.17 & 0.20 & 0.36 \\
\hline \multirow{5}{*}{ LM } & 1 & 86.45 & 11.39 & 76.09 & 1.15 & 1.06 & 2.15 & -0.21 & -0.04 & -0.25 \\
\hline & 2 & 85.64 & 12.88 & 75.69 & 2.60 & 1.82 & 1.80 & 0.85 & -0.18 & -0.59 \\
\hline & 3 & 79.08 & 9.75 & 65.64 & 2.90 & 2.39 & 4.06 & 0.37 & 0.71 & -0.19 \\
\hline & 4 & 74.81 & 9.23 & 67.00 & 2.07 & 1.35 & 3.56 & 0.45 & 0.34 & 3.13 \\
\hline & 5 & 77.39 & 7.82 & 60.75 & 3.22 & 2.07 & 6.19 & -0.51 & 0.50 & 4.80 \\
\hline \multirow{5}{*}{ NM } & 1 & 77.43 & 20.80 & 74.69 & 2.67 & 0.92 & 1.75 & 0.82 & 0.13 & 0.54 \\
\hline & 2 & 72.68 & 25.55 & 75.79 & 1.98 & 1.05 & 1.53 & 0.15 & -0.21 & -0.14 \\
\hline & 3 & 68.49 & 26.73 & 73.46 & 2.96 & 0.98 & 1.83 & 0.40 & -0.30 & 0.18 \\
\hline & 4 & 58.88 & 18.94 & 70.76 & 2.58 & 2.56 & 2.74 & -0.60 & -0.69 & 1.15 \\
\hline & 5 & 54.58 & 18.61 & 71.71 & 3.47 & 2.19 & 2.68 & -0.55 & -0.09 & 0.45 \\
\hline
\end{tabular}
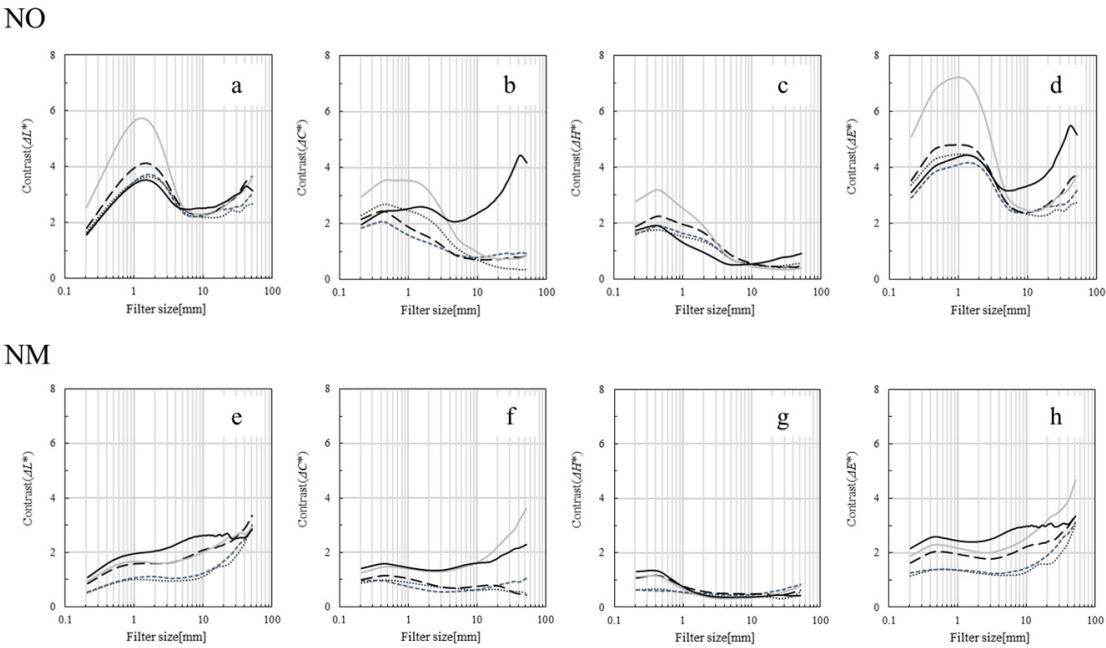

Fig. 4 Four kinds of contrast spectra $\left(\Delta L^{*}, \Delta C^{*}, \Delta H^{*}\right.$ and $\left.\Delta E^{*}\right)$ derived by multi-resolution contrast analysis. Upper: natural oak (NO), lower: natural maple (NM)

Table 1 に, 全試料の色彩值の平均值, 標準偏差, 歪度 を示す．各試料のヒストグラムの特徴は, Table 1 に示し た色彩值の各種統計量にも反映されている。 ヒストグラ ムのシフトは平均值の変化であり, 分布の広がり具合は 標準偏差の大小で表される. また, ヒストグラムの裾野が 值の小さい側あるいは大きい側に展延すれば，歪度がそ れぞれ負あるいは正に大きくなる。このように，ヒストグ ラム解析によって,「古さ」の変化を材面の全体的な色調 変化として捉えることが可能であった．

$3 \cdot 1 \cdot 2$ 多重解像度コントラスト解析 ヒストグラム 解析では材面の全体的な色調の変化を把握できたが，多 重解像度コントラスト解析 (MRCA) では, 材面の局所的 な色の変化を捉えることができる．典型的なコントラス トスペクトルとして, NO 系統およびNM 系統の明度 $L^{*}$, 彩度 $C^{*}$, 色相 $H^{*}$, そして色差 $E^{*}$ のコンラストスペク トルを Fig. 4 に示す. 明度, 彩度, 色相のスペクトルは言 わば色差のスペクトルの内訳に相当する. NO 系統の場合,
「古く」なるにつれてフィルタサイズ 1〜2 mm での明度 コントラスト $\Delta L^{*}$ と彩度コントラスト $\Delta C^{*}$ が増大した(Fig. $4 \mathrm{a}$ および $4 \mathrm{~b})$. このフィルタサイズはオーク材の孔圈幅に 対応していると考えられ，暗い孔圈部と明るい周囲材と の差がコントラストとして検出されたと考えられる．た だし，この系統で最も「古い」試料 5 では，このフィルタ サイズでの明度コントラスト $\Delta L^{*}$ が小さくなった(Fig. 4a). これは孔圈部が目立ちにくくなったことを意味している. 同様のコントラストスペクトルの変化は DO 系統におい ても認められた.

一方, NM 系統のスペクトルにはオークのようなピーク が認められず，「古く」なるにつれてフィルタサイズにか かわらず明度コントラスト $\Delta L^{*}$ と彩度コントラスト $\Delta C^{*}$ が増大している(Fig. 4e および 4f). これは LM 系統でも同 様であった。

$10 \mathrm{~mm}$ 以上のフィルタサイズにおけるコントラストは, 材面に散在する色ムラや污れに対応していると考えられ 

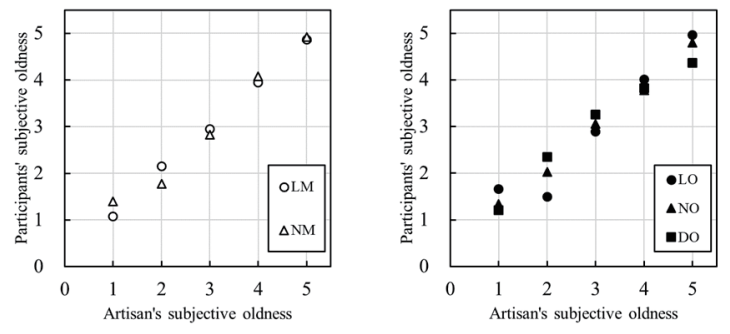

Fig. 5 Relationships between participants' subjective oldness and artisan's subjective oldness.

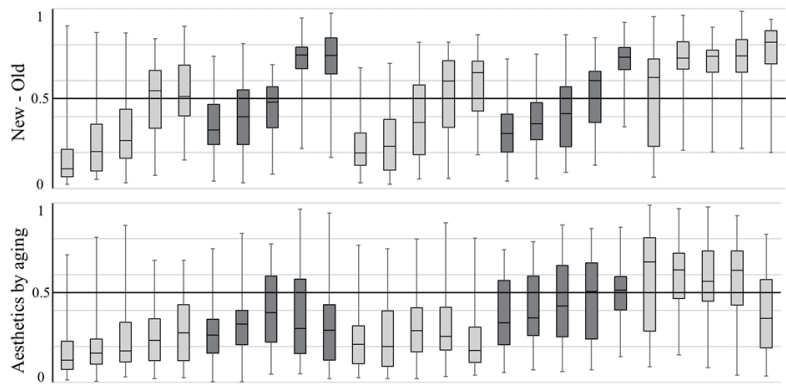

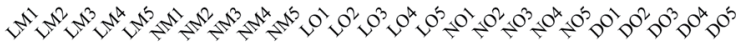

Fig. 6 Box-and-whisker plots of "new - old" (upper) and "aesthetics by aging" (lower).

る.このフィルタサイズでの色差コントラスト $\Delta E^{*}$ は「古 く」なるにつれて増大した(Fig. 4d および4h). ただし， ラ イト，ナチュラル，ダークの基本色によって，色差の内訳 が異なっており，LO 系統では明度コントラスト $\Delta L^{*}$ の増 大が， $\mathrm{NO}$ 系統では彩度コントラスト $\Delta C^{*}$ の増大が， DO 系統では明度コントラスト $\Delta L^{*}$ と彩度コントラスト $\Delta C^{*}$ 双方の増大が，それぞれ色差コントラスト $\Delta E^{*}$ の増大に 強く効いた。また DO 系統および LM 系統と NM 系統で は，最も「古い」試料 5 で大きなフィルタサイズでの明度 コントラスト $\Delta L^{*}$ と彩度コントラスト $\Delta C^{*}$ が小さくなり， 試料 4 などと比べて色ムラが目立ちにくくなった.

\section{$3 \cdot 2$ 主観評価}

3・2・1 順位付け評価 被験者にまず行わせた順位付 け評価では，系統別に5つの試料の見た目の「古さ」に順 位を付けた。最も「新しい」と評価された試料から順に 1 〜5の点数を与えることにして，全被験者の点数を試料ご とに集計し，平均值を求めた。Fig. 5 は，塗装職人が意困 した古さ (横軸) と，被験者が主観的に評価した古さ（縦 軸）の関係を示している. NO，DO，LM，NM 系統では， 被験者の評価は塗装職人の意図と完全に一致した。一方, LO 系統では，試料 1 よりも試料 2 の方が「新しい」と評価 された，先に述べたように，「古く」なるほど明度ヒスト グラムは暗い側にシフトした（Fig. 3)。しかし，Table 1 の平均明度にも現れているように，LO 系統の試料 2 は試 料 1 よりも明るくなっており，そのため多くの被験者が LO2 の方が LO1 よりも新しいと評価する逆転現象が生じ たものと考えられる.ただし, 古さの順位に逆転が生じた のはLO1 と LO2 のみであり，その差もわずかなので，塗 装職人の意図した「古さ」は概数正しく伝わったものとい える.
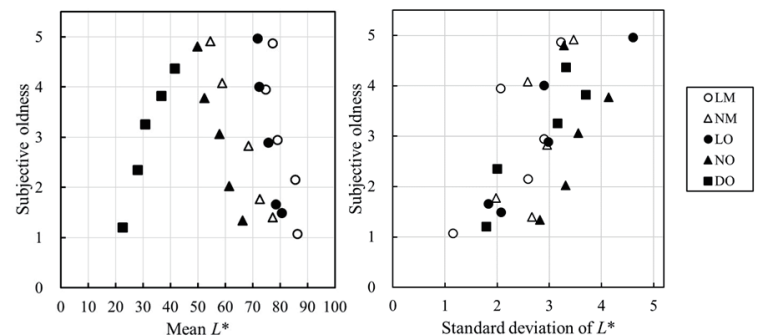

Fig. 7 Relationships between subjective oldness and image statistics (left: mean $L^{*}$, right: standard deviation of $L^{*}$ ).
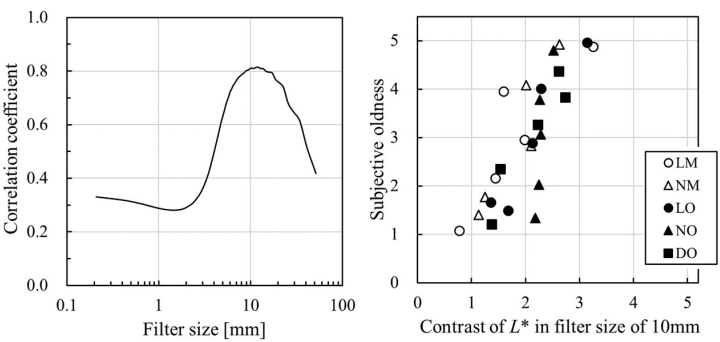

Fig. 8 Relationships between subjective oldness and contrast values (right). The optimum filter size $(10 \mathrm{~mm})$ for contrast values is found in correlation coefficient spectrum (left) which represents whole relationships between subjective oldness and contrast values of $L^{*}$ in any filter size.

$\mathbf{3} \cdot \mathbf{2} \cdot \mathbf{2}$ 印象評価 VAS 法による各試料の印象評価の 一例を Fig. 6 亿箱ひげ図で示す． Fig. 6 上側は「新しい— 古い」，下側は「経年による美しさ」の評価であり，箱の 長さが四分位範囲を, 箱内の線分が中央值を, ひげの上端 と下端がそれぞれ最大值と最小值を表している。 今回調 查したいずれの印象においても被験者による評価のばら つきが大きく，古さとの明確な対応関係が認められなか った．なお，Fig. 6下側の「経年による美しさ」は，同一 系統内での変化よりも基本材色の影響を強く受け, 材色 が暗い方が「美しい」と評価される傾向にあった。

$3 \cdot 3$ 画像特徵量と「古さ」の関係 色彩值の各種統計 量と「古さ」の関係について, 系統別に検証したところ, 平均明度 $L * お よ ひ ゙$ 明度 $L * の$ 標準偏差の影響が大きかった。 これらの統計量と「古さ」の関係を Fig. 7 亿示す. DO系 統以外では, 平均明度が大きい (明るい) ほど「新しい」 と評価されたが，DO 系統では，明るくなるほど「古い」 と評価された（Fig. 7 左）。また，いずれの系統において も, 材面の明度の標準偏差が大きくなるほど「古い」と評 価される傾向にある (Fig.7 右)。これらのことから, 材面 の明るさや, 色のバリエーション, つまりコントラストの 大小が，材面の古さの評価に大きな影響を与えていると いえる.

ぞのくらいの大きさの特徵が「古さ」に影響を与えやす いのかを知るために, MRCA から得られたコントラスト 值と「古さ」の平均順位の相関分析を行った. Fig. 8 左は, 任意のフィルタサイズでの明度コントラストと「古さ」の 順位の相関係数スペクトルで, フィルタサイズ $10 \mathrm{~mm}$ 付 近で相関係数が最大となっている.このことは大きさ約 $10 \mathrm{~mm}$ の特徵におけりる明暗変化が「古さ」によく効くこと を示唆する. Fig. 8 右は, フィルタサイズ $10 \mathrm{~mm}$ での明度 


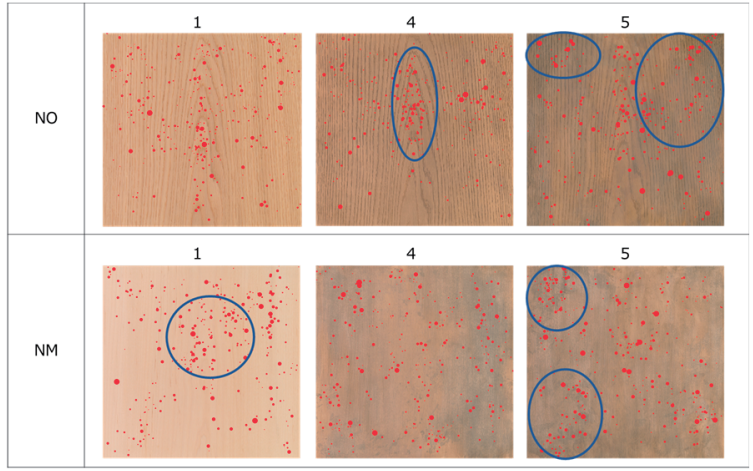

Fig. 9 Gaze plot of natural oak and natural maple specimens. Area of the dots corresponds to an accumulated fixation time. Circles show the concentration of the red dots.

コントラストと「古さ」の平均順位の関係で, 相関係数 0.85 を超える強い正の相関関係が認められた。この大きさ $10 \mathrm{~mm}$ 程度の特徵は, 材面に散在する色ムラや污れの一部 に対応しており，色ムラや污れが「古さ」に影響を与える ことを示唆している.

$3 \cdot 4$ 視線追跡実験＼cjkstart視線追跡実験は，材面が「古く」 なると被験者の視線の引きやすさすなわち誘目性がどの ように変化するのかを把握するために行われた．Fig. 9 は NO 系統および NM 系統の試料を自由観察したときに被 験者の視線がどこによく停留したかを表す停留点分布図 である. 両系統の試料 $1,4,5$ について, 自由観察開始直後 10 秒間の停留座標と時間が全被験者分累積されてマッピ ングされている. 点の大きさは停留時間の長さを表す.今 回の停留判定は, 注視点が視野角 $0.8^{\circ}$ の範囲に 0.1 秒以上 留まるという条件で行った。 また，1秒閒を超える視線の 停留は不自然に長いと考え, 停留点から除外した. だ円は 停留点が密集する領域を示す.

$\mathrm{NO}$ 系統では，3 試料のいずれにおいても中央部の山形 模様の連なりに視線が集中している. なかでも, MRCA の コントラストスペクトルにおいてフィルタサイズ 1～2 $\mathrm{mm}$ のコントラストが最も大きかった試料 4 では, 山形模 様の頂点部に特に停留が集中している.

NM 系統では,「新しい」材面である試料 1 の停留点は, ピスフレックと呼ばれる線状の虫害痕や試料の中央部に 集中する傾向にある。「古く」なるにつれて古色付けによ ってピスフレックが目立たなくなり，周辺部の污れや色 ムラに停留点が分散している.

以上は停留点分布に関する定性的な分析であるが，才 一ク材に現れる山形模様のような際立つ特徵に視線が集 中するのと同時に，材面の污れや色ムラにも十分な停留 が生じる様子が現れており, 経年による誘目性の変化が 材面の印象に影響を及ぼしたものと考えられる.

\section{4 結 言}

エイジングによる木材の外観の変化を画像解析によっ て数量表現し，その見た目の印象および誘目性との対応 関係を検証した。
ヒストグラム解析によって材面の全体的な色調の変化 を, また, MRCA によって材面の局所的な特徵の変化を 捉えることができ, エイジングの進行と画像特徵量の変 化を関連付けることができた。

主観的な見た目の「古さ」には, 材面の平均明度や明度 の標準偏差が影響するとともに，10 mm 程度の大きさで 現れる材面の局所的な明暗変化が効いていることが示唆 された. 寸なわち, 材面の明るさやコントラストの大小が, 木材の古さの主観的な評価に大きく影響する

さらに, 視線追跡実験によって, 観察者の視線は特徵的 な木目柄や材面の污れ, 色么ラに集中しやすいことが客 観的に示され，そのような視線の集中する領域の特徵が 材面の印象に効くことが示唆された.

ただし, 本研究が対象とした材面のエイジングは, 塗装 によって擬似的に表現されたものである．実際の木材の エイジングとの比較や，樹種や材色によるエイジング特 性の相違が誘目性や印象に及ぼす影響について，今後さ らに検証する必要がある。

\section{参 考 文 献}

1) M. Matsuo, M. Yokoyama, K. Umemura, J. Sugiyama, S. Kawai, J. Gril, S. Kubodera, T. Mitsutani, H. Ozaki, M. Sakamoto and M. Imamura, "Aging of wood: Analysis of color changes during natural aging and heat treatment", Holzforschung, Vol.65, pp.361-368 (2011).

2) M. Matsuo, K. Umemura and S. Kawai, "Kinetic analysis of color changes in keyaki (Zelkova serrata) and sugi (Cryptomeria japonica) wood during heat treatment", Journal of Wood Science, Vol. 60, pp.12-20 (2014)

3) L. Tolvaj and K. Mitsui, "Correlation between hue angle and lightness of light irradiated wood", Polymer Degradation and Stability, Vol.95, pp.638-642 (2010)

4) L. Oltean, A. Teischinger and C. Hansmann, "Wood surface discolouration due to simulated indoor sunlight exposure", Holz Roh Werkst, Vol.66, pp.51-56 (2008)

5) T. Tashiro and M. Nakamura, "Characterization of colors distributed on lumber surface by imaging spectroscopy", Journal of the Society of Materials Science, Japan, Vol.62, No.4, pp.248-253(2013)

6) M. Nakamura, M. Masuda and K. Shinohara, "Multiresolutional image analysis of wood and other materials", Journal of Wood Science, Vol. 45, pp.10-18 (1999)

7) M. Nakamura, M. Matsuo and T. Nakano, "Determination of the change in appearance of lumber surfaces illuminated from various directions", Holzforschung, Vol.64, 251-257 (2010).

8) M. Nakamura, Y. Miyake and T. Nakano, "Effect of image characteristics of edge-grain patterns on visual impressions", Journal of Wood Science, Vol. 58, pp.505-512 (2012) 